\title{
Chemical Composition, Allelopathic, Antioxidant, and Anti-Inflammatory Activities of Sesquiterpenes Rich Essential Oil of Cleome amblyocarpa Barratte \& Murb.
}

\author{
Ahmed M. Abd-ElGawad 1,2,*化, Abdelbaset M. Elgamal ${ }^{3}$, Yasser A. EI-Amier ${ }^{1} \mathbb{D}$, Tarik A. Mohamed ${ }^{4}$, \\ Abd El-Nasser G. El Gendy ${ }^{5}$ (D) and Abdelsamed I. Elshamy ${ }^{6, * \mathbb{D}}$ \\ check for \\ updates \\ Citation: Abd-ElGawad, A.M.; \\ Elgamal, A.M.; EI-Amier, Y.A.; \\ 1 Department of Botany, Faculty of Science, Mansoura University, Mansoura 35516, Egypt; \\ yasran@mans.edu.eg \\ 2 Plant Production Department, College of Food \& Agriculture Sciences, King Saud University, P.O. Box 2460, \\ Riyadh 11451, Saudi Arabia \\ 3 Department of Chemistry of Microbial and Natural Products, National Research Centre, 33 El-Bohouth St., \\ Dokki, Giza 12622, Egypt; algamalnrc_2010@nrc.sci.eg \\ 4 Chemistry of Medicinal Plants Department, National Research Centre, 33 El-Bohouth St., Dokki, \\ Giza 12622, Egypt; ta.mourad@nrc.sci.eg \\ 5 Medicinal and Aromatic Plants Research Department, National Research Centre, 33 El Bohouth St., Dokki, \\ Giza 12622, Egypt; ag.el-gendy@nrc.sci.eg \\ 6 Chemistry of Natural Compounds Department, National Research Centre, 33 El Bohouth St., Dokki, \\ Giza 12622, Egypt \\ * Correspondence: aibrahim2@ksu.edu.sa (A.M.A.-E.); ai.el-shamy@nrc.sci.eg (A.I.E.); \\ Tel.: +00966562680864 (A.M.A.-E.); +201005525108 (A.I.E.)
}

Mohamed, T.A.; El Gendy, A.E.-N.G.; I. Elshamy, A. Chemical Composition, Allelopathic, Antioxidant, and Anti-Inflammatory Activities of Sesquiterpenes Rich Essential Oil of Cleome amblyocarpa Barratte \& Murb. Plants 2021, 10, 1294. https:// doi.org/10.3390/plants10071294

Academic Editors: Hazem Salaheldin Elshafie, Laura De Martino and Adriano Sofo

Received: 25 May 2021

Accepted: 23 June 2021

Published: 25 June 2021

Publisher's Note: MDPI stays neutral with regard to jurisdictional claims in published maps and institutional affiliations.

Copyright: (C) 2021 by the authors Licensee MDPI, Basel, Switzerland. This article is an open access article distributed under the terms and conditions of the Creative Commons Attribution (CC BY) license (https:/ / creativecommons.org/licenses/by/ $4.0 /)$.
Abstract: The integration of green natural chemical resources in agricultural, industrial, and pharmaceutical applications allures researchers and scientistic worldwide. Cleome amblyocarpa has been reported as an important medicinal plant. However, its essential oil (EO) has not been well studied; therefore, the present study aimed to characterize the chemical composition of the C. amblyocarpa, collected from Egypt, and assess the allelopathic, antioxidant, and anti-inflammatory activities of its EO. The EO of C. amblyocarpa was extracted by hydrodistillation and characterized via gas chromatography-mass spectrometry (GC-MS). The chemometric analysis of the EO composition of the present studied ecospecies and the other reported ecospecies was studied. The allelopathic activity of the EO was evaluated against the weed Dactyloctenium aegyptium. Additionally, antioxidant and anti-inflammatory activities were determined. Forty-eight compounds, with a prespondence of sesquiterpenes, were recorded. The major compounds were caryophyllene oxide (36.01\%), hexahydrofarnesyl acetone (7.92\%), alloaromadendrene epoxide $(6.17 \%)$, myrtenyl acetate $(5.73 \%)$, isoshyobunone $(4.52 \%)$, shyobunol $(4.19 \%)$, and trans-caryophyllene $(3.45 \%)$. The chemometric analysis revealed inconsistency in the EO composition among various studied ecospecies, where it could be ascribed to the environmental and climatic conditions. The EO showed substantial allelopathic inhibitory activity against the germination, seedling root, and shoot growth of D. aegyptium, with $\mathrm{IC}_{50}$ values of $54.78,57.10$, and $74.07 \mathrm{mg} \mathrm{L}^{-1}$. Additionally, the EO showed strong antioxidant potentiality based on the $\mathrm{IC}_{50}$ values of $4.52 \mathrm{mg} \mathrm{mL}^{-1}$ compared to $2.11 \mathrm{mg} \mathrm{mL}^{-1}$ of the ascorbic acid as standard. Moreover, this oil showed significant anti-inflammation via the suppression of lipoxygenase (LOX) and cyclooxygenases (COX1, and COX2), along with membrane stabilization. Further study is recommended for analysis of the activity of pure authentic materials of the major compounds either singularly or in combination, as well as for evaluation of their mechanism(s) and modes of action as antioxidants or allelochemicals.

Keywords: phytotoxicity; environmental factors; volatile oils; Cleome genus; anti-inflammation 


\section{Introduction}

Wild plants are considered green factories for the synthesis of thousands of bioactive compounds that have various biological activities and are integrated into the treatment of various diseases, controlling weeds as biocides, as well as being used in agricultural, industrial, and pharmaceutical applications [1]. The use of natural bioactive compounds instead of synthetic chemicals fascinates scientists, researchers, and policymakers because they are renewable, degradable, safe, and low toxic [2,3].

Essential oils (EOs) are the main constituents of the members of the plant kingdom [4]. Historically, EOs represented one of the main resources of significant pharmaceutical and biological agents because of their complicated chemical composition, basically as isoprenoids [5]. Many biological potentialities for EOs have been described as hepatoprotective, anticancer [4], antioxidant [6,7], anti-inflammatory [8], anti-aging [4], antipyretic [6], and antimicrobial [9], in addition to allelopathy [10-12].

Cleome amblyocarpa Barr. \& Murb. (Syns: Cleome arabica var. amblyocarpa (Barratte \& Murb.) Ozenda, Cleome africana Botsch., or Cleome daryoushiana Parsa) is a herbaceous plant of the Cleomaceae family [13]. It is widely growing in sandy or stony habitats of desert along with North Africa [14]. This plant has been used in folk medicine for the treatment of various diseases such as diabetes and colic, as a stomachic therapy, rheumatic fever, scabies, and inflammation [15]. Various bioactive compounds have been isolated from C. amblyocarpa, such as flavonoids and glucosinolates [16], saponins [17], triterpenoids [18]. Therefore, this herb has been reported to possess various biological activities, including antiinflammatory [16], anti-COVID-19 [17], genotoxicity [9], antidiabetic and antioxidant [19], and antimicrobial effects [20].

The EOs of several species of genus Cleome have been studied, such as C. droserifolia [21], C. trinervia [22], C. monophylla [23], and C. serrata [24], C. coluteoides [25]. However, few studies have dealt with the EO of C. amblyocarpa [26]. Additionally, and to the best of our knowledge, the allelopathic activity of the $\mathrm{EO}$ of $C$. amblyocarpa has not been studied before. Therefore, the present study aimed to (1) characterize the chemical composition of the EO isolated from the Egyptian ecospecies of $C$. amblyocarpa, and (2) evaluate the allelopathic activity, antioxidant, and anti-inflammatory activities of its EO.

\section{Results and Discussion}

\subsection{EO Composition of C. amblyocarpa}

The hydrodistillation of the air-dried powder of the above-ground parts of $C$. amblyocarpa yielded $0.38 \%(v / w)$ of golden-yellow oil. Depending upon the GC-MS analysis (Figure 1), 48 compounds were characterized, representing $97.17 \%$ of the total mass (Table 1). The Egyptian ecospecies of the present study yielded higher EO yield compared to Iranian [27] and Saudi [28] ecospecies, which had 0.20 and $0.21 \%$, respectively. This variation in oil production could be ascribed to environmental, climatic, or genetic factors [5,6,29-31]. The term "ecospecies" means that species of the plant can be divided into several ecotypes (a genetically distinct population of plants that is growing in a particular habitat). 
Table 1. Chemical components of the essential oil of above-ground parts of Cleome amblyocarpa.

\begin{tabular}{|c|c|c|c|c|c|c|c|}
\hline No. & $\mathrm{RT}^{\mathrm{a}}$ & $\mathrm{RC}^{\mathrm{b} \%}$ & Compound Name & $\mathbf{M F}^{\mathrm{c}}$ & $\mathrm{KI}_{\text {Lit }}{ }^{\mathrm{d}}$ & $\mathrm{KI}_{\operatorname{Exp}} \mathrm{e}^{\mathrm{e}}$ & Identification $\mathrm{f}$ \\
\hline \multicolumn{8}{|c|}{ Oxygenated monoterpenes } \\
\hline 1 & 6.60 & 0.50 & 6-Camphenol & $\mathrm{C}_{10} \mathrm{H}_{16} \mathrm{O}$ & 1113 & 1113 & KI, MS \\
\hline 2 & 8.94 & 0.13 & Eucalyptol & $\mathrm{C}_{10} \mathrm{H}_{18} \mathrm{O}$ & 1031 & 1032 & KI, MS \\
\hline 3 & 10.24 & 0.54 & Camphor & $\mathrm{C}_{10} \mathrm{H}_{16} \mathrm{O}$ & 1146 & 1165 & KI, MS \\
\hline 4 & 11.00 & 0.45 & Isopulegol & $\mathrm{C}_{10} \mathrm{H}_{18} \mathrm{O}$ & 1149 & 1150 & KI, MS \\
\hline 5 & 12.76 & 1.12 & Borneol & $\mathrm{C}_{10} \mathrm{H}_{18} \mathrm{O}$ & 1169 & 1169 & KI, MS \\
\hline 6 & 11.99 & 0.25 & 2-ethyl-exo-Fenchol & $\mathrm{C}_{10} \mathrm{H}_{18} \mathrm{O}$ & 1297 & 1299 & KI, MS \\
\hline 7 & 26.43 & 5.73 & Myrtenyl acetate & $\mathrm{C}_{12} \mathrm{H}_{18} \mathrm{O}_{2}$ & 1326 & 1324 & $\mathrm{KI}, \mathrm{MS}$ \\
\hline \multicolumn{8}{|c|}{ Sesquiterpenes hydrocarbons } \\
\hline 8 & 16.34 & 0.13 & Silphiperfol-5,7(14)-diene & $\mathrm{C}_{15} \mathrm{H}_{22}$ & 1360 & 1361 & $\mathrm{KI}, \mathrm{MS}$ \\
\hline 9 & 17.28 & 0.98 & $\alpha$-Copaene & $\mathrm{C}_{15} \mathrm{H}_{24}$ & 1376 & 1378 & $\mathrm{KI}, \mathrm{MS}$ \\
\hline 10 & 17.48 & 1.01 & $\beta$-Maaliene & $\mathrm{C}_{15} \mathrm{H}_{24}$ & 1380 & 1381 & KI, MS \\
\hline 11 & 17.70 & 0.47 & Berkheyaradulene & $\mathrm{C}_{15} \mathrm{H}_{24}$ & 1388 & 1389 & KI, MS \\
\hline 12 & 18.68 & 3.45 & trans-Caryophyllene & $\mathrm{C}_{15} \mathrm{H}_{24}$ & 1408 & 1410 & KI, MS \\
\hline 13 & 18.79 & 0.29 & Widdrene & $\mathrm{C}_{15} \mathrm{H}_{24}$ & 1431 & 1430 & KI, MS \\
\hline 14 & 19.22 & 0.46 & $\beta$-Humulene & $\mathrm{C}_{15} \mathrm{H}_{24}$ & 1438 & 1436 & KI, MS \\
\hline 15 & 19.85 & 0.49 & $\beta$-Farnesene & $\mathrm{C}_{15} \mathrm{H}_{24}$ & 1442 & 1443 & KI, MS \\
\hline 16 & 20.47 & 0.53 & $\gamma$-Muurolene & $\mathrm{C}_{15} \mathrm{H}_{24}$ & 1479 & 1477 & KI, MS \\
\hline 17 & 20.78 & 0.23 & ar-Curcumene & $\mathrm{C}_{15} \mathrm{H}_{22}$ & 1480 & 1481 & KI, MS \\
\hline 18 & 20.86 & 0.54 & Valencene & $\mathrm{C}_{15} \mathrm{H}_{24}$ & 1496 & 1496 & KI, MS \\
\hline 19 & 20.94 & 0.65 & $\alpha$-Selinene & $\mathrm{C}_{15} \mathrm{H}_{24}$ & 1498 & 1497 & KI, MS \\
\hline 20 & 21.20 & 2.30 & $\alpha$-Muurolene & $\mathrm{C}_{15} \mathrm{H}_{24}$ & 1500 & 1500 & KI, MS \\
\hline 21 & 21.78 & 1.17 & $\alpha$-Bulnesene & $\mathrm{C}_{15} \mathrm{H}_{24}$ & 1509 & 1510 & $\mathrm{KI}, \mathrm{MS}$ \\
\hline 22 & 22.00 & 1.02 & $\gamma$-Cadinene & $\mathrm{C}_{15} \mathrm{H}_{24}$ & 1513 & 1514 & KI, MS \\
\hline 23 & 23.55 & 0.42 & trans-Calamenene & $\mathrm{C}_{15} \mathrm{H}_{22}$ & 1522 & 1520 & KI, MS \\
\hline 24 & 32.80 & 1.01 & $\alpha$-Guaiene & $\mathrm{C}_{15} \mathrm{H}_{24}$ & 1600 & 1601 & $\mathrm{KI}, \mathrm{MS}$ \\
\hline \multicolumn{8}{|c|}{ Oxygenated sesquiterpenes } \\
\hline 25 & 20.21 & 0.13 & $\beta$-Cubebene & $\mathrm{C}_{15} \mathrm{H}_{24} \mathrm{O}$ & 1388 & 1389 & KI, MS \\
\hline 26 & 21.53 & 1.53 & trans- $\alpha$-Bisabolene epoxide & $\mathrm{C}_{15} \mathrm{H}_{24} \mathrm{O}$ & 1506 & 1508 & KI, MS \\
\hline 27 & 21.67 & 1.54 & trans-Nerolidol & $\mathrm{C}_{15} \mathrm{H}_{24} \mathrm{O}$ & 1531 & 1533 & KI, MS \\
\hline 28 & 23.17 & 4.52 & Isoshyobunone & $\mathrm{C}_{15} \mathrm{H}_{24} \mathrm{O}$ & 1571 & 1570 & KI, MS \\
\hline 29 & 23.48 & 0.66 & Spathulenol & $\mathrm{C}_{15} \mathrm{H}_{24} \mathrm{O}$ & 1577 & 1579 & KI, MS \\
\hline 30 & 23.78 & 36.01 & Caryophyllene oxide & $\mathrm{C}_{15} \mathrm{H}_{24} \mathrm{O}$ & 1582 & 1584 & KI, MS \\
\hline 31 & 24.22 & 0.86 & Humulene oxide & $\mathrm{C}_{15} \mathrm{H}_{24} \mathrm{O}$ & 1608 & 1609 & KI, MS \\
\hline 32 & 24.45 & 0.83 & Junenol & $\mathrm{C}_{15} \mathrm{H}_{26} \mathrm{O}$ & 1619 & 1621 & KI, MS \\
\hline 33 & 24.53 & 0.56 & Citronellyl valerate & $\mathrm{C}_{15} \mathrm{H}_{28} \mathrm{O}_{2}$ & 1625 & 1626 & KI, MS \\
\hline 34 & 24.63 & 1.18 & Nerolidol-epoxyacetate & $\mathrm{C}_{17} \mathrm{H}_{28} \mathrm{O}_{4}$ & 1638 & 1637 & KI, MS \\
\hline 35 & 24.88 & 0.38 & tau-Cadinol & $\mathrm{C}_{15} \mathrm{H}_{26} \mathrm{O}$ & 1640 & 1639 & KI, MS \\
\hline 36 & 25.34 & 6.17 & Alloaromadendrene epoxide & $\mathrm{C}_{15} \mathrm{H}_{24} \mathrm{O}$ & 1641 & 1643 & KI, MS \\
\hline 37 & 25.57 & 0.71 & $\alpha$-Eudesmol & $\mathrm{C}_{15} \mathrm{H}_{26} \mathrm{O}$ & 1653 & 1655 & KI, MS \\
\hline 38 & 25.80 & 0.32 & Aromadendrene oxide-(2) & $\mathrm{C}_{15} \mathrm{H}_{24} \mathrm{O}$ & 1678 & 1680 & KI, MS \\
\hline 39 & 25.99 & 4.19 & Shyobunol & $\mathrm{C}_{15} \mathrm{H}_{24} \mathrm{O}$ & 1688 & 1691 & KI, MS \\
\hline 40 & 26.79 & 0.49 & $\beta$-Santalol & $\mathrm{C}_{15} \mathrm{H}_{24} \mathrm{O}$ & 1738 & 1735 & KI, MS \\
\hline 41 & 29.32 & 0.54 & Xanthorrhizol & $\mathrm{C}_{15} \mathrm{H}_{22} \mathrm{O}$ & 1753 & 1752 & KI, MS \\
\hline \multicolumn{8}{|c|}{ Diterpenes hydrocarbons } \\
\hline 42 & 33.47 & 0.22 & Geranyl- $\alpha$-terpinene & $\mathrm{C}_{20} \mathrm{H}_{32}$ & 1874 & 1872 & $\mathrm{KI}, \mathrm{MS}$ \\
\hline \multicolumn{8}{|c|}{ Oxygenated diterpenes } \\
\hline 43 & 37.49 & 0.17 & Phytol & $\mathrm{C}_{20} \mathrm{H}_{40} \mathrm{O}$ & 1942 & 1944 & $\mathrm{KI}, \mathrm{MS}$ \\
\hline \multicolumn{8}{|c|}{ Carotenoid derived compounds } \\
\hline 44 & 14.56 & 1.39 & Theaspirane A & $\mathrm{C}_{13} \mathrm{H}_{22} \mathrm{O}$ & 1305 & 1307 & KI, MS \\
\hline 45 & 14.87 & 1.64 & Dihydroedulan II & $\mathrm{C}_{13} \mathrm{H}_{22} \mathrm{O}$ & 1318 & 1316 & KI, MS \\
\hline \multicolumn{8}{|c|}{ Apocarotenoid derived compounds } \\
\hline 46 & 30.87 & 7.92 & Hexahydrofarnesyl acetone & $\mathrm{C}_{18} \mathrm{H}_{36} \mathrm{O}$ & 1835 & 1837 & $\mathrm{KI}, \mathrm{MS}$ \\
\hline \multicolumn{8}{|c|}{ Other compounds } \\
\hline 47 & 13.87 & 1.16 & p-Isopropyl-benzaldehyde & $\mathrm{C}_{10} \mathrm{H}_{12} \mathrm{O}$ & 1239 & 1240 & KI, MS \\
\hline 48 & 38.11 & 0.18 & 9,12-Octadecadienoic acid & $\mathrm{C}_{18} \mathrm{H}_{32} \mathrm{O}_{2}$ & 2085 & 2085 & KI, MS \\
\hline \multicolumn{2}{|c|}{ Total } & 97.17 & & & & & \\
\hline
\end{tabular}

${ }^{a}$ RT: Retention time. ${ }^{\mathbf{b}}$ RC: Relative concentration. ${ }^{\mathbf{c}}$ MF: Molecular formula. ${ }^{\mathbf{d}} \mathrm{KI}_{\mathrm{Lit}}$ : Kovats retention index according to Adams (2017) on a DB-5 column in reference to $n$-alkanes. ${ }^{e} \mathrm{KI}_{\text {Exp }}$ : Experimental calculated Kovats retention index. ${ }^{\mathrm{f}} \mathrm{EO}$ constituent identification was constructed via compound mass spectra (MS) and Kovats retention indices (KI) with those of Wiley spectral library collection and NIST library databases. 


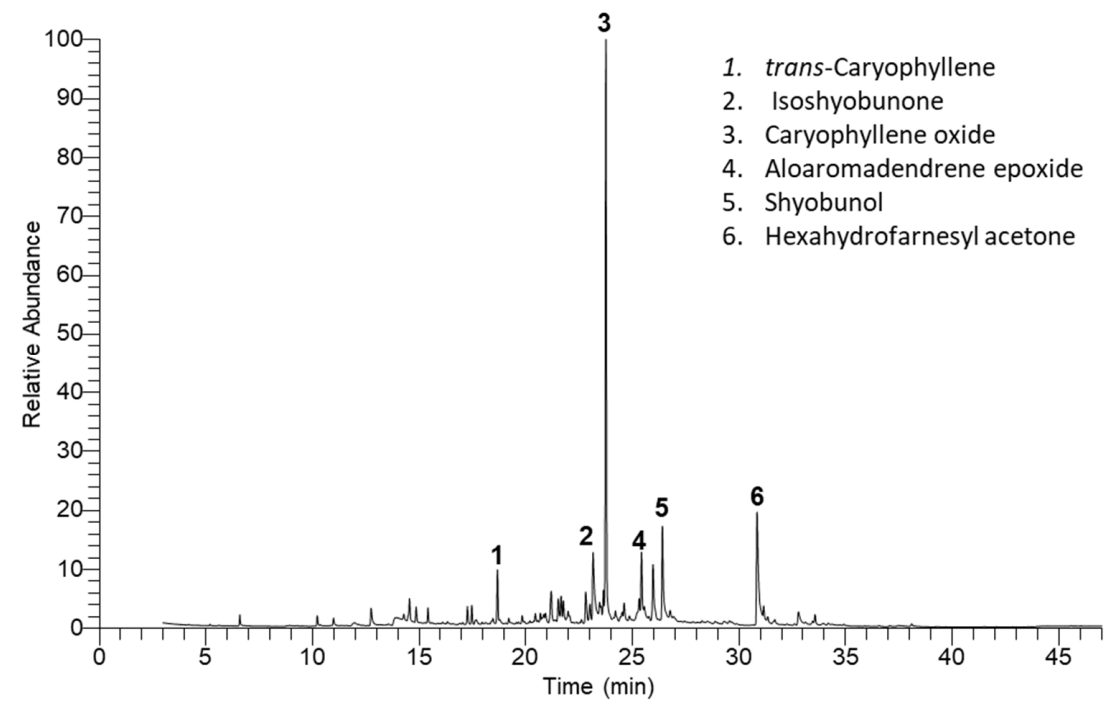

Figure 1. Chromatogram of the chemical compounds identified via GC-MS in the EO of Cleome amblyocarpa above-ground parts. The major compound peaks are numbered (1-6).

In the EO of $C$. amblyocarpa, six classes of components were determined, comprising oxygenated sesquiterpenes, sesquiterpenes hydrocarbons, oxygenated monoterpenes, diterpenes hydrocarbons, oxygenated diterpenes, apocarotenoid-derived compounds, carotenoid-derived compounds, and other compounds (Figure 2). These compounds pooled as $81.80 \%$ oxygenated compounds and $15.37 \%$ as non-oxygenated compounds. From overall mass, terpenoids represented the main constituents with a relative $84.88 \%$ with a preponderance of sesquiterpenes $(75.77 \%)$, a remarkable concentration of monoterpenes $(8.72 \%)$, and traces of diterpenes $(0.39 \%)$. The abundance of terpenoids in the EO of $C$. amblyocarpa was in agreement with the data reported for samples collected from Iran [27] and the United Arab Emirates [26]. In contrast, the plurality of sesquiterpenes was inconsistent with the Iranian C. amblyocarpa, in which diterpenoids were determined as the major class [27], and C. amblyocarpa collected from the United Arab Emirates, in which monoterpenes were the main constituents [26]. These significant variations of chemical composition might be ascribed to environmental circumstances (such as temperature, rainfall, soil factors, altitude, etc.) and genetic characteristics [11,30,32,33].

a

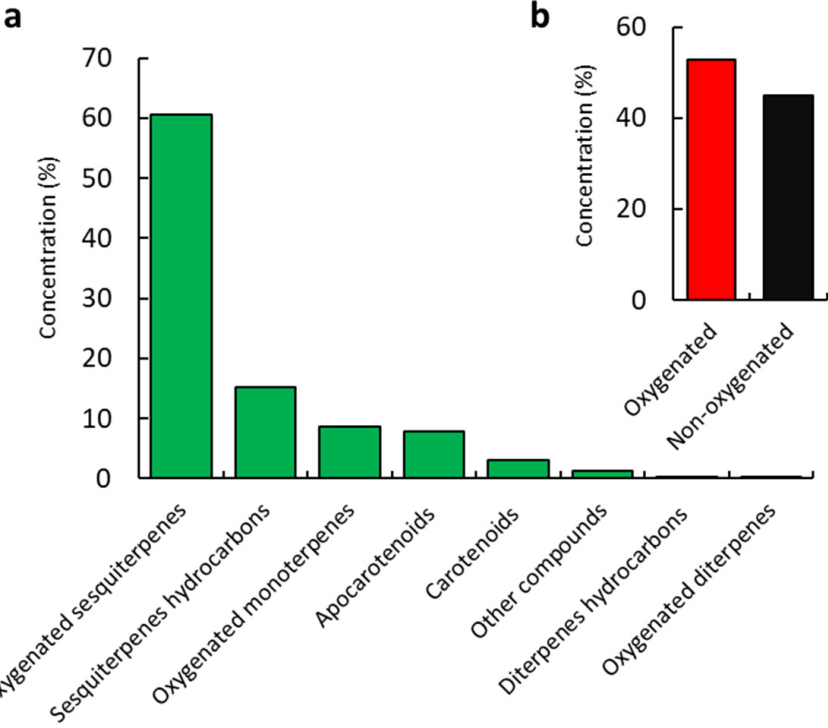

Figure 2. Concentrations of various identified classes of the chemical compounds of the Cleome amblyocarpa $\mathrm{EO}(\mathbf{a})$ and the percentage of oxygenated and non-oxygenated compounds (b). 
Sesquiterpenes were assigned as the main components involving the oxygenated compounds as majors $(60.62 \%)$ in addition to a relative concentration of $15.15 \%$ of sesquiterpene hydrocarbons. Out of the 16 identified oxygenated sesquiterpenes, caryophyllene oxide $(36.01 \%)$, alloaromadendrene epoxide $(6.17 \%)$, isoshyobunone $(4.52 \%)$, and shyobunol $(4.19 \%)$ represented the major compounds, whereas $\beta$-cubebene $(0.13 \%)$ was the minor compound. Caryophyllene oxide is a common major compound in several EOs derived from plants such as Cullen plicata [34], Schinus polygamus [35], Curcuma sahuynhensis [36]. Caryophyllene oxide was documented as a minor compound in the EO of Iranian C. amblyocarpa [27], and totally absent from the EO of C. amblyocarpa collected from the United Arab Emirates [26], Tunisia [37], and Saudi Arabia [28]. On the other hand, trans-caryophyllene $(3.45 \%)$, and $\alpha$-muurolene $(2.30 \%)$ were found to be the main sesquiterpene hydrocarbons, whereas silphiperfol-5,7(14)-diene $(0.13 \%)$ was determined as a minor component. transcaryophyllene has been reported in trace amounts of the EO of the Iranian ecospecies of C. amblyocarpa [27], whereas it is completely absent from the EO of Saudi [28], Emirati [26], and Tunisian [37] ecospecies.

The oxygenated monoterpenes were represented by $8.72 \%$, which contained seven compounds, with myrtenyl acetate $(5.73 \%)$ and borneol $(1.12 \%)$ as major compounds. These two compounds are totally absent from the other ecospecies of C. amblyocarpa [26-28,37]. On the other hand, low diterpene contents were determined and represented by two compounds, geranyl- $\alpha$-terpinene $(0.22 \%)$ and phytol $(0.17 \%)$. However, diterpenes were absent from other ecospecies of $C$. amblyocarpa. In other species of Cleome genus, phytol was reported in a high concentration such as C. monophylla [23], C. serrata [24], and C. serrata [38].

Carotenoid-derived compounds were determined in a concentration of $3.03 \%$, that represented only two compounds, dihydroedulan II (1.64\%) and theaspirane A (1.39\%). Only one apocarotenoid-derived compound, hexahydrofarnesyl acetone, was identified with a high relative concentration $(7.92 \%)$, whereas it was completely absent from the other reported ecospecies of C. amblyocarpa [26-28,37]. Hexahydrofarnesyl acetone is a widely distributed major compound in the EOs of several plants such as Bassia muricata [10], Heliotropium curassavicum [33], Hildegardia barteri [39], Trianthema portulacastrum [40].

Finally, traces of other non-terpenoid components were characterized including only two compounds, $p$-isopropy-l-benzaldehyde (1.16\%) and 9,12-octadecadienoic acid (0.18\%).

\subsection{Chemometric Analysis of the EOs from Different C. amblyocarpa Ecospecies}

The chemometric analysis of the EO composition of the present studied C. amblyocarpa and other reported ecospecies (Saudi, Iranian, Tunisian, and Emirati) was performed using cluster analysis and PCA (Figure 3). The cluster analysis revealed substantial variations among the studied ecospecies, and we can categorize them into three groups: group I comprising the present Egyptian and Tunisian ecospecies, group II containing Emirati and Iranian ecospecies, and finally the Saudi ecospecies separated alone as group III (Figure 3a). Interestingly, the chemometric analysis revealed that the EO compositions of ecospecies from the nearest countries were similar. This observation reflects the effect of environmental and climatic factors $[30,32,33]$.

However, the present studied C. amblyocarpa ecospecies showed a correlation with the caryophyllene oxide, hexahydrofarnesyl acetone, and shyobunol, whereas the Tunisian ecospecies showed a correlation with ethyl 3-methylpentanoate, 7-epi-silphiperfol-5-ene, $\alpha$ copaene, and 1,8-cineole (Figure 3b). The Saudi ecospecies was characterized by cis-dihydro carvone, 2-methoxy-4-vinyl phenol, and cubebene heptanal.

\subsection{Allelopathic Effect of the C. amblyocarpa EO}

The EO of C. amblyocarpa showed significant allelopathic activity of the seed germination $(p<0.05)$ as well as the shoot and root development of $D$. aegyptium in a dose-dependent manner (Figure 4a). At the highest concentration $\left(100 \mu \mathrm{g} \mathrm{mL}^{-1}\right)$, the germination was inhibited by $70.18 \%$, whereas the seedling root and shoot were reduced by $75.88 \%$ and $61.87 \%$, respectively. Based on the $\mathrm{IC}_{50}$ values, the root was more affected than the shoot, 
where the roots had an $\mathrm{IC}_{50}$ value of $57.10 \mu \mathrm{g} \mathrm{mL}{ }^{-1}$, and the root attained $74.07 \mu \mathrm{g} \mathrm{mL}^{-1}$ (Figure $4 \mathrm{~b}$ ). Root has been reported to be more affected by allelochemicals than the shoot. This observation was reported for many plant species such as Deverra tortuosa [41], Teucrium polium [42], Calotropis procera [5], Ficus carica [43], and C. plicata [34]. This could be ascribed to the direct contact of the root with the medium and the high permeability of root cells $[34,44]$.

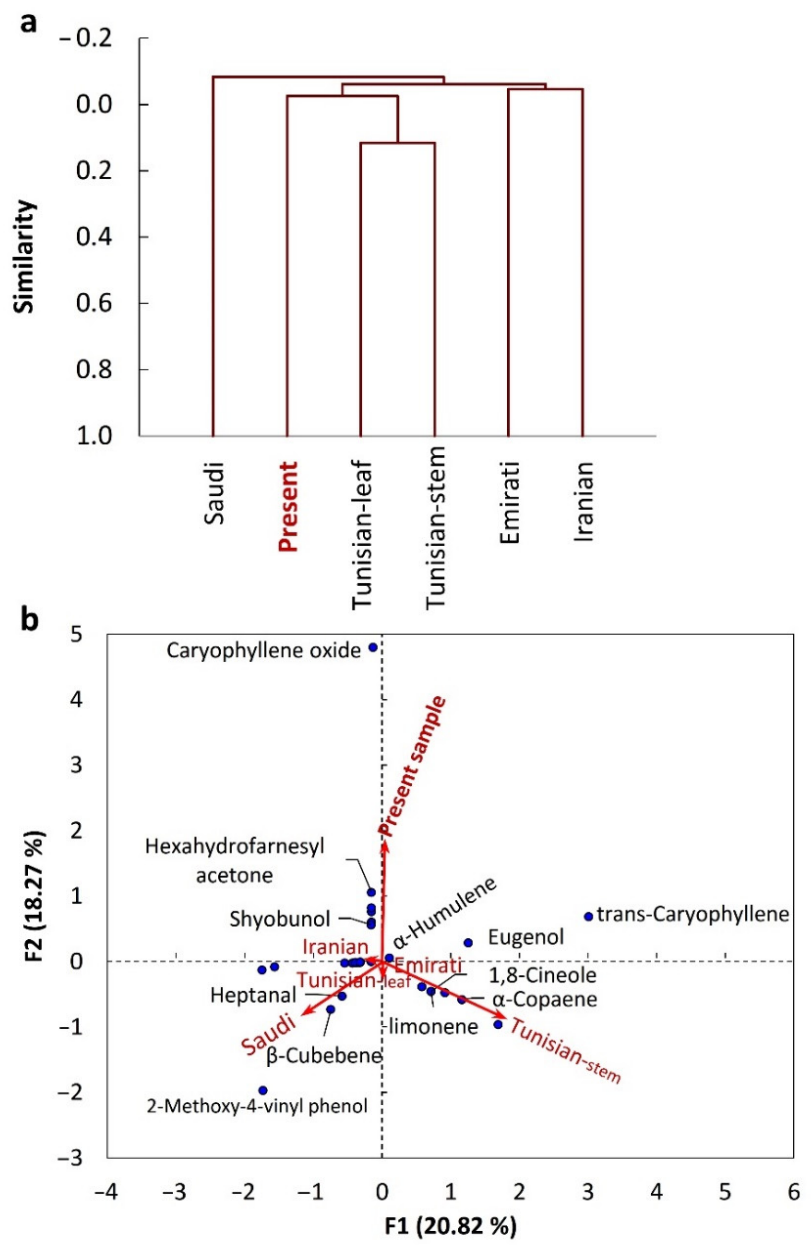

Figure 3. Chemometric analysis of various Cleome amblyocarpa ecospecies. (a) agglomerative hierarchical clustering (AHC), (b) and principal components analysis (PCA). (F1) and (F2) are factor 1 and 2.

a

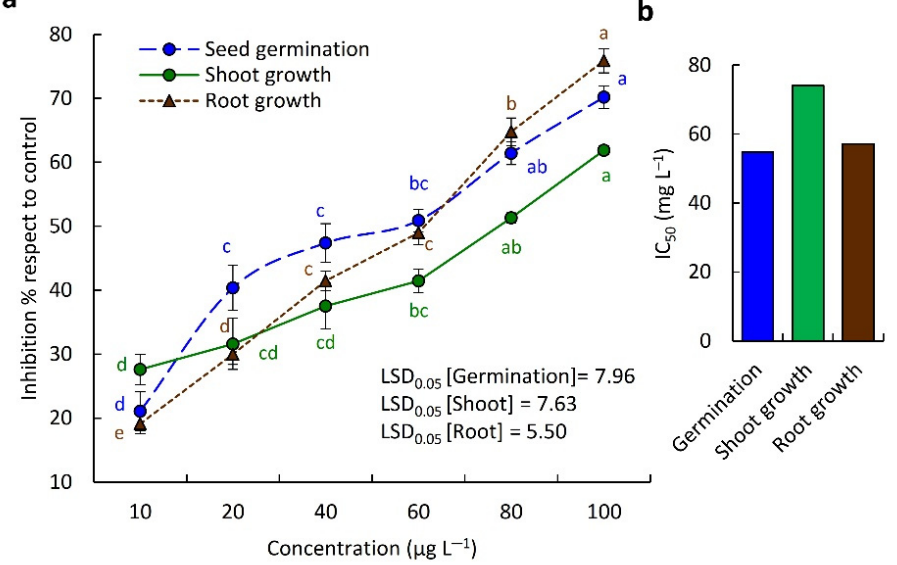

Figure 4. Allelopathic activity of the EO from the above-ground parts of Cleome amblyocarpa on the germination, root and shoot growth of Dactyloctenium aegyptium. (a) Various concentration and (b) $\mathrm{IC}_{50}$. Different letters within each line mean values significantly different at $p<0.05$ (Tukey's HSD test). 
To the best of our knowledge, the allelopathic activity of the EO from C. amblyocarpa has not been studied yet. However, the aqueous, hexane, chloroform, and methanol extracts from C. amblyocarpa have been reported to inhibit lettuce germination and growth [45]. At a concentration of $6 \mathrm{~g} \mathrm{~L}^{-1}$, ethyl acetate showed a complete inhibition of lettuce growth, whereas Peganum harmala, Raphanus sativus, and Silybum marianum were more resistant. Additionally, Ladhari et al. [46] identified some terpenoids and flavonoids from C. amblyocarpa, where dammarane-type triterpenes showed strong allelopathic activity, and flavonoid compounds exhibited $<50 \%$ inhibition of the targeted species.

In our results, the allelopathic activity of $C$. amblyocarpa $\mathrm{EO}$ could be attributed to the activity of a single or combination of the major identified compounds. Caryophyllene oxide is reportedly a major compound of the EOs with substantial allelopathic activity such as C. plicata [34], H. curassavicum [33], Acroptilon repens [47], Teucrium arduini, T. montbretii [48], and Nepeta curviflora [49]. On the other hand, the EO from Launaea mucronata and L. nudicaulis showed the presence of hexahydrofarnesyl acetone as a major compound, where it revealed significant allelopathic activity against the weed: Portulaca oleracea [30]. Additionally, the EO of H. curassavicum had hexahydrofarnesyl acetone as the main compound, and showed marked allelopathic activity on Chenopodium murale [33]. The major compound, alloaromadendrene epoxide, in the $\mathrm{EO}$ of the present $\mathrm{C}$. amblyocarpa has also been reported as the main compound $(7.32 \%)$ of the EOs from Lactuca serriola that showed allelopathic activity against the weed Bidens pilosa [50]; however, in the EO of Calamintha nepeta, it did not show significant allelopathic activity against Raphanus sativus, Lepidium sativum, Sinapis arvensis, Triticum durum, and Phalaris canariensis [51]. This inconsistency could be attributed to the resistance of the weeds and shows that allelochemicals are species-specific [52].

Generally, the oxygenated terpene compounds have been reported to possess allelopathic activity compared to the non-oxygenated compounds [6]. In the present study, the EO of C. amblyocarpa was very rich in oxygenated compounds $(81.80 \%)$, which could explain the notable allelopathic activity.

\subsection{Antioxidant Activity of C. amblyocarpa EO}

The activity of $C$. amblyocarpa $\mathrm{EO}$ in the reduction in the DPPH revealed significant antioxidant activity in a dose-dependent manner (Figure 5). At the lowest concentration of the EO $\left(10 \mathrm{mg} \mathrm{mL}^{-1}\right)$, the EO showed a $15.28 \%$ scavenging activity of the DPPH, whereas at the highest concentration $\left(100 \mathrm{mg} \mathrm{mL}^{-1}\right)$, the antioxidant activity was reduced by $3.7-$ fold of the lowest concentration of the $\mathrm{EO}$. Based on the $\mathrm{IC}_{50}$, the C. amblyocarpa $\mathrm{EO}$ had a value of $4.52 \mathrm{mg} \mathrm{mL}^{-1}$ compared to $2.11 \mathrm{mg} \mathrm{mL}^{-1}$ of the ascorbic acid as a standard antioxidant. The antioxidant activity of EOs in the present study were lower than those reported from Tunisian ecospecies [37]. This could be ascribed to the variation in the EO chemical compositions (Table 1).

The free radical scavenging activities of plant extracts and/or EOs were directly correlated with the concentration of the oxygenation of their constituents due to the increase in the free electrons [53]. The present data revealed $81.08 \%$ of oxygenated compounds, which means that a wealth of free electrons can act to diminish free radicals in the evaluation reaction. More specifically, the activity of this EO may be attributed to the activity of major compounds, either singularly or in synergy. Caryophyllene oxide has been reported to possess antioxidant activity [34]. EOs rich in hexahydrofarnesyl, such as B. muricata [10] and H. curassavicum [33], showed substantial antioxidant activity. The EO extracted from L. serriola has been reported to be rich in alloaromadendrene epoxide and isoshyobunone, where it expressed strong antioxidant activity [50]. 

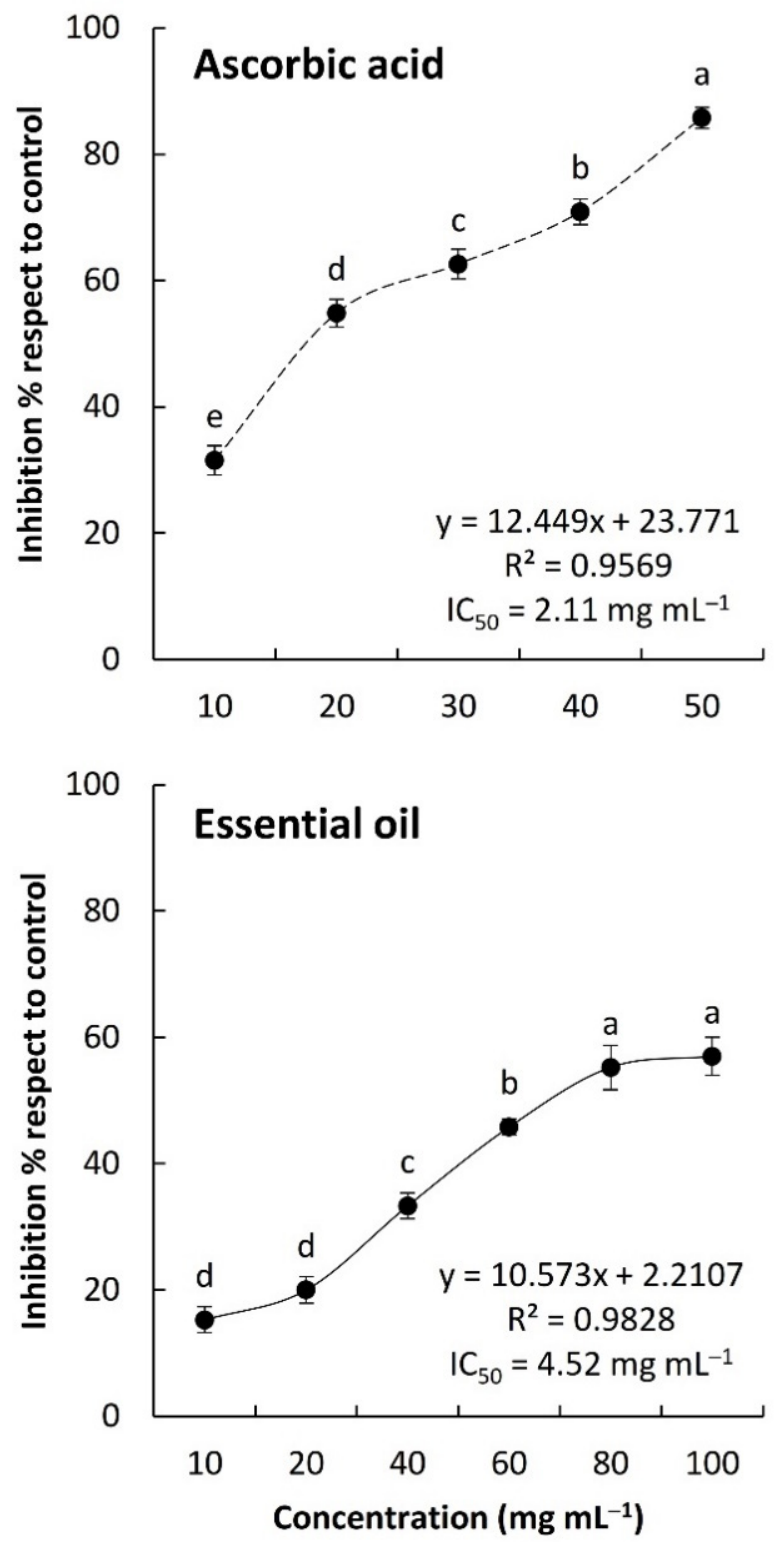

Figure 5. Antioxidant activity of the EO from the above-ground parts of Cleome amblyocarpa. Different letters of the line mean values significant at $p<0.05$ (Tukey's HSD test).

\subsection{Anti-Inflammatory effect of C. amblyocarpa EO}

For the first time, the anti-inflammatory of EO of $C$. amblyocarpa has been evaluated via inhibition of the enzymes, lipoxygenase (LOX), cyclooxygenases (COX1, and COX2), as well as membrane stabilization. The results presented in Figure 6 revealed that the EO exhibited a significant anti-inflammatory action via the inhibition of LOX, COX1, and COX2 with respective $\mathrm{IC}_{50}$ values of $1.67,12.77,13.43 \mu \mathrm{g} \mathrm{mL}{ }^{-1}$, whereas ibuprofen showed inhibition with $\mathrm{IC}_{50}$ values of $1.53,10.26$, and $12.71 \mu \mathrm{g} \mathrm{mL} \mathrm{m}^{-1}$, respectively. Additionally, the EO significantly inhibited the lysis of the hypotonic solution of the RBCs at an $\mathrm{IC}_{50}$ value of $15.25 \mu \mathrm{g} \mathrm{mL}{ }^{-1}$, compared with indomethacin which presented a result of $14.34 \mu \mathrm{g} \mathrm{mL}^{-1}$. 


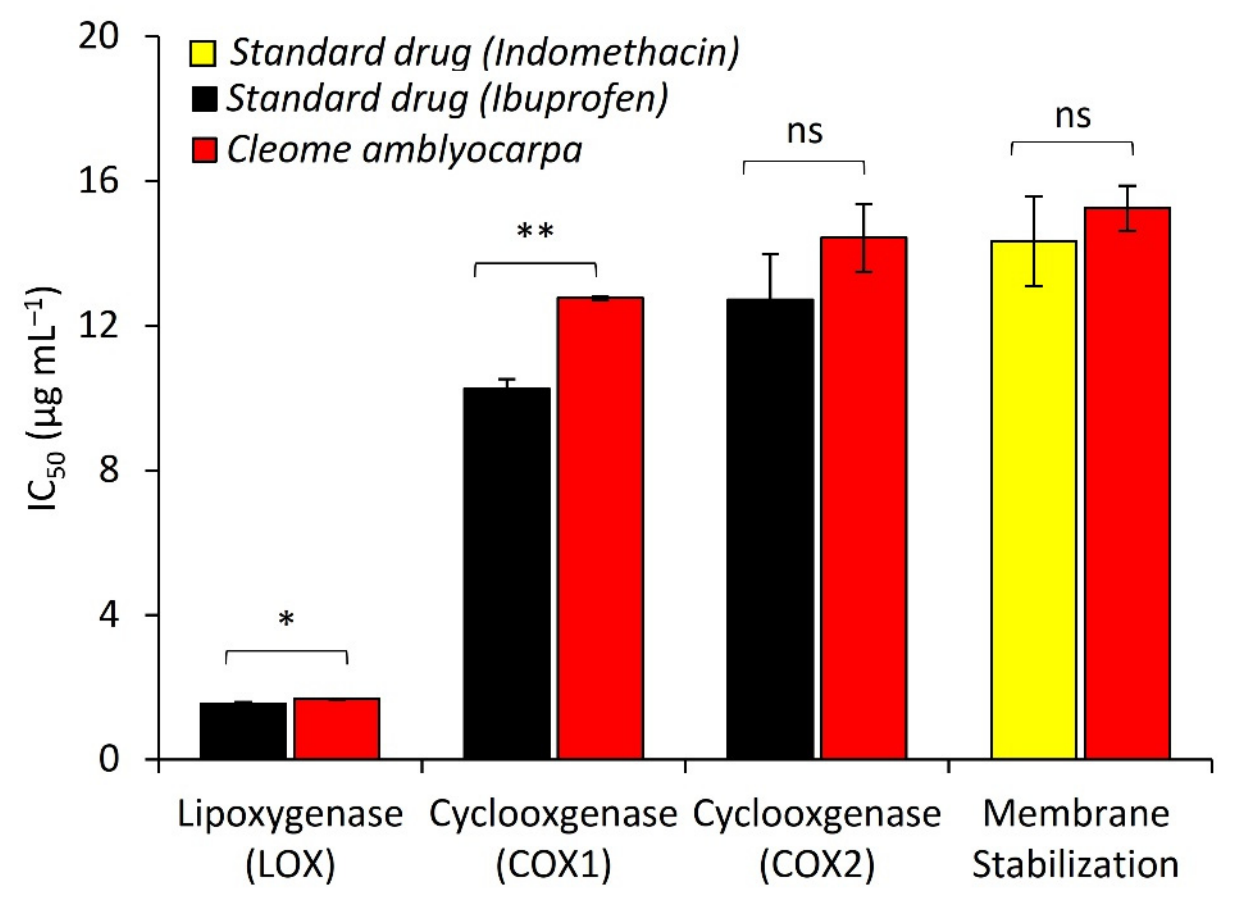

Figure 6. The anti-inflammatory activity of the EO of Cleome amblyocarpa, based on membrane stabilizing, and the inhibition of lipoxygenase (LOX) and cyclooxygenase (COX1 and COX 2). (ns) non-significant, ${ }^{*} p<0.05,{ }^{* *} p<0.01$ (two-tailed $t$-test). Data are mean values \pm standard error $(n=4)$.

These data revealed that this EO has potent anti-inflammatory potentialities comparable with the two reference drugs, ibuprofen, and indomethacin, especially via the inhibition of lipoxygenase (LOX) and cyclooxygenase (COX1). This capability of EO for the inhibition of inflammations might be directly ascribed to the terpenoid contents as the main components (84.88\%) [54]. Terpenoids represented major components of many of the documented plants with significant anti-inflammatory potentialities such as Araucaria heterophylla [8], Ocimum basilicum [55], and Limnophila indica [56].

Many studies have deduced that volatile sesquiterpene compounds have a potent anti-inflammation role in in vivo and in vitro models, especially caryophyllene and its oxide form [57]. Chavan et al. [58] described that the caryophyllene oxide, isolated from Annona squamosa, has significant in vivo anti-inflammatory activity. EO derived from Cordia verbenacea as well as its active constituent, caryophyllene, were demonstrated to exhibit strong anti-inflammatory activity was discussed with regard to their interfering with the production of TNF- $\alpha$ [59]. Moreover, Medeiros et al. [60] described that trans-caryophyllene showed potent anti-inflammatory in rats by significantly decreasing the migration of neutrophils as well as increasing the NF- $\mathrm{kB}$-induced stimulation by lipopolysaccharides.

The EO of Sardinian Santolina corsica has been reported to contain a remarkable content of aromadendrene derivatives that exhibit a significant anti-inflammatory [61]. The enriched EO of Algerian Myrtus communis with myrtenyl acetate (38.7\%) was shown to reduce the mice's inflammation and paw edema at a concentration of $100 \mathrm{mg} / \mathrm{kg}$ [62]. In addition to these significant roles of the main components, the other compounds were expected to have an important contribution via synergetic effects [8]. Based upon all these reported data, it is very clear that the present data agree with the previously documented. Additionally, the present results could be attributed to the prevalence of sesquiterpenes, especially trans-caryophyllene and caryophyllene oxide. 


\section{Materials and Methods}

\subsection{Plant Materials}

Composite samples of the above-ground parts of the flowering C. amblyocarpa were collected in May 2018 from Wadi Hajoul, eastern desert, Egypt $\left(29^{\circ} 57^{\prime} 51.2^{\prime \prime}\right.$ N $\left.32^{\circ} 08^{\prime} 57.9^{\prime \prime} \mathrm{E}\right)$ The flowering plant was presented in Figure 7 The samples were collected from two populations in plastic bags, transferred to the laboratory, air-dried in a shaded place at room temperature for seven days, crushed into powder, and stored in paper bags until further analysis. The plant was identified according to [63,64]. A herbarium sheet (Mans.030301002) was prepared and deposited in the Herbarium of Botany Department, College of Science, Mansoura University, Egypt.

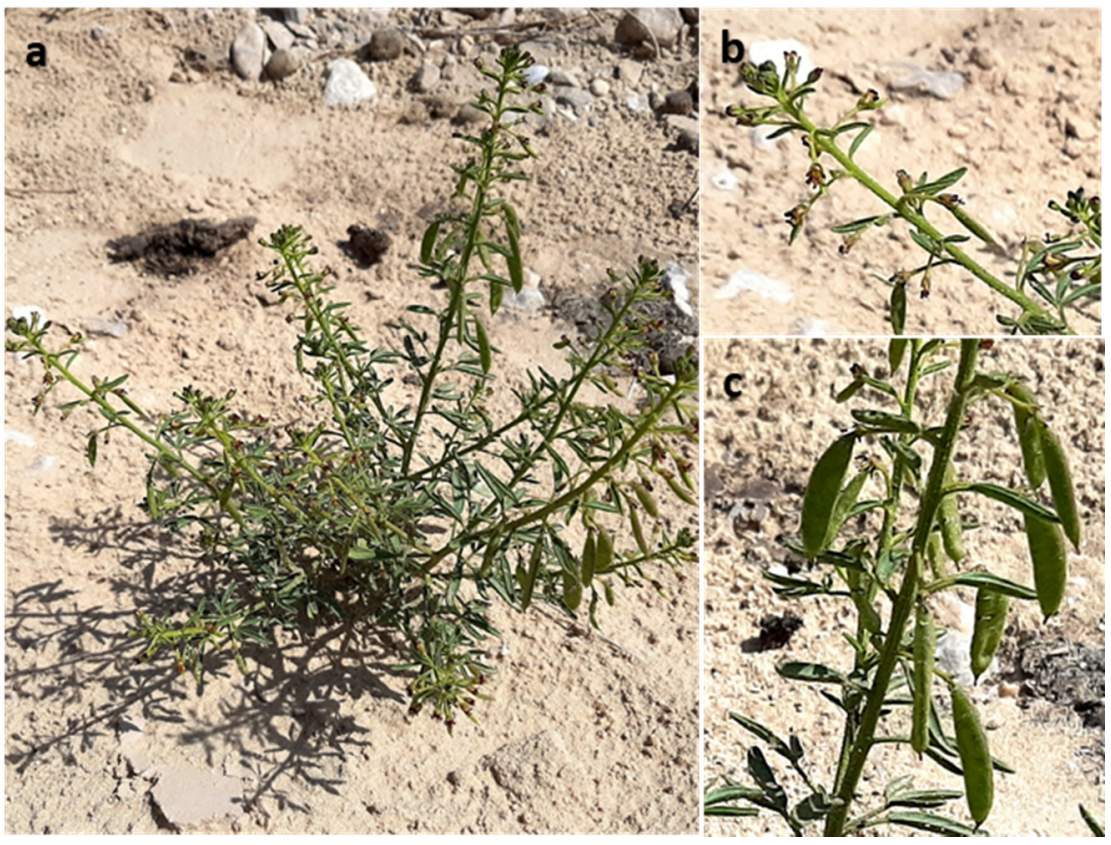

Figure 7. Cleome amblyocarpa Barratte \& Murb. (a) Whole flowering plant, (b) enlarged flowering branch, and (c) enlarged fruiting branch. Photos were taken by Dr. Yasser El-Amier during spring of the year 2018 in Wadi Hajoul, eastern desert, Egypt.

\subsection{EO Extraction Analysis and Characterization}

The EO chemical compositions of the two extracted EO samples were analyzed and identified separately by gas chromatography-mass spectrometry (GC-MS), as described in our previous publication [65].

\subsection{Allelopathic Bioassay}

The allelopathic activity of the extracted EO from the above-ground parts of C. amblyocarpa was evaluated in vitro against the weed, Dactyloctenium aegyptium. The ripe seeds of the weed were collected from a cultivated field near Gamasa city, northern Mediterranean coast, Egypt $\left(31^{\circ} 26^{\prime} 19.3^{\prime \prime} \mathrm{N} 31^{\circ} 34^{\prime} 12.9^{\prime \prime} \mathrm{E}\right)$. The uniform seeds were surface-sterilized with sodium hypochlorite $(0.3 \%)$, rinsed with distilled sterilized water, and dried under sterile conditions [34]. To test the allelopathic activity, serial concentrations $\left(10-100 \mu \mathrm{g} \mathrm{mL}^{-1}\right)$ of the EO were prepared using 1\% polysorbate 80 (Sigma-Aldrich, Darmstadt, Germany) as an emulsifier. In a Petri plate, 20 sterilized seeds of D. aegyptium were arranged over wetted Whatman filter paper (Sigma-Aldrich, Darmstadt, Germany), either with each concentration or polysorbate 80 (as positive control). The plates were sealed with Parafilm ${ }^{\circledR}$ tape (Sigma, St. Louis, MO, USA) and kept in a growth chamber adjusted at $25^{\circ} \mathrm{C}$.

The plates were checked every day, and after 7 days, the number of germinated seeds was counted, and the lengths ( $\mathrm{mm})$ of seedling roots and shoots were measured. The 
inhibition of the germination, root growth, and shoot growth of seedlings was calculated according to the following equation:

$$
\text { Inhibition }(\%)=100 \times\left(\frac{\text { Number } / \text { Length }_{\text {control }}-\left(\text { Number } / \text { Length }_{\text {treatment }}\right)}{\text { Number } / \text { Length }_{\text {control }}}\right)
$$

Additionally, the $\mathrm{IC}_{50}$, which is the concentration of the $\mathrm{EO}$ required for $50 \%$ inhibition of seed germination or seedling growth, was calculated by linear regression of the inhibition values versus various EO concentrations using MS-EXCEL 2016.

\subsection{Antioxidant Activity}

The antioxidant activity of the EO from C. amblyocarpa was estimated based on its ability to reduce the stable radical, 2,2-diphenyl-1-picrylhydrazyl (DPPH). According to the method of Miguel [66], a reaction mixture of an equal volume of $0.3 \mathrm{mM}$ of freshly prepared DPPH and serial concentrations (10-100 mg mL $\mathrm{mL}^{-1}$ ) of the EO or ascorbic acid as standard was prepared and well shaken. The mixture was incubated in dark conditions at room temperature $\left(25 \pm 2{ }^{\circ} \mathrm{C}\right)$ for $30 \mathrm{~min}$. The absorbance was measured at $517 \mathrm{~nm}$ using a spectrophotometer (Spectronic 21D model). The scavenging activity was estimated according to the following equation:

$$
\text { Scavengingactivity }(\%)=100 \times\left(1-\frac{\text { Absorbance }_{\text {sample }}}{\text { Absorbance }_{\text {control }}}\right)
$$

The $\mathrm{IC}_{50}$, which is the concentration of the EO required to reduce the color of the DPPH by 50\%, was calculated graphically by linear regression using MS-EXCEL 2016.

\subsection{Anti-Inflammatory Activity Estimation}

The anti-inflammatory activity of the EO from the above-ground parts of C. amblyocarpa was evaluated by assessing the in vitro membrane stabilizing, and inhibition of lipoxygenase (LOX, EC: 1.13.11.12) and cyclooxygenase (COX1 and COX 2, EC: 1.14.99.1) enzymes.

\subsubsection{Membrane Stabilization Inhibition Assay}

The membrane-stabilizing activity of the samples was assessed using hypotonic solution-induced erythrocyte (RBCs) hemolysis [67]. For the preparation of erythrocyte suspension, whole blood was obtained with heparinized syringes from rats through cardiac puncture. The blood was washed three times with isotonic buffered solution (154 mM $\mathrm{NaCl}$ ) in $10 \mathrm{mM}$ sodium phosphate buffer ( $\mathrm{pH} 7.4$ ) and immediately centrifuged for $10 \mathrm{~min}$ at $3000 \times g$. The test sample consisted of stock erythrocyte suspension $(0.5 \mathrm{~mL}), 5 \mathrm{~mL}$ of hypotonic solution ( $50 \mathrm{mM} \mathrm{NaCl})$, and the C. amblyocarpa EO $\left(7.81-1000 \mu \mathrm{g} \mathrm{mL}{ }^{-1}\right.$ in ethanol) or indomethacin (as a standard drug). The control sample consisted of $0.5 \mathrm{~mL}$ of stock erythrocyte suspension and hypotonic-buffered saline solution alone. The mixtures were incubated for $10 \mathrm{~min}$ at room temperature $\left(25 \pm 2{ }^{\circ} \mathrm{C}\right)$ and centrifuged for $10 \mathrm{~min}$ at $3000 \times g$. In 96-well plates, the absorbance of the supernatant was measured at $540 \mathrm{~nm}$. The percentage inhibition of hemolysis or membrane stabilization were calculated according to the modified method described by Shinde et al. [67] as follows:

$$
\text { Inhibition } \%=100 \times\left[\left(\mathrm{A}_{\text {control }}-\mathrm{A}_{\text {treatment }}\right) \div \mathrm{A}_{\text {control }}\right]
$$

where $\mathrm{A}_{\text {control }}$ is the absorbance control, and $\mathrm{A}_{\text {treatment }}$ is the absorbance treatment.

The $\mathrm{IC}_{50}$ value was defined as the concentration of the EO required to inhibit $50 \%$ of the RBC hemolysis under the assay conditions. It was calculated graphically by linear regression of the inhibition values of different concentrations using MS-EXCEL 2016.

\subsubsection{Lipoxygenase (LOX) Inhibition Assay}

The activity of the C. amblyocarpa $\mathrm{EO}$ on the inhibition of the LOX enzyme (type I-B) was determined according to Granica et al. [68], with slight modifications. Briefly, in 96-well 
plates, $100 \mu \mathrm{L}$ of soybean (Glycine max) LOX solution $(1000 \mathrm{U} / \mathrm{mL}$ in borate buffer solution, $\mathrm{pH} 9$ ) and $200 \mu \mathrm{L}$ of borate buffer were mixed together with various concentrations of either EO (to a final concentration range of $0.98-125 \mu \mathrm{g} \mathrm{mL}{ }^{-1}$ ) or ibuprofen as a reference drug. Samples were pre-incubated with $100 \mu \mathrm{L}$ of linoleic acid (substrate) to initiate the reaction and then were incubated at $25^{\circ} \mathrm{C}$ for $15 \mathrm{~min}$. The absorbance increase was measured at $234 \mathrm{~nm}$ using a microplate reader (BioTek Instruments Inc., Winooski, VT, USA). The inhibition percentage and $\mathrm{IC}_{50}$ were calculated as previously mentioned in the membrane stabilization inhibition assay.

\subsubsection{Cyclooxygenase (COX 1 and COX 2) Inhibition Assay}

The COX activity was monitored as a result of the oxidation reaction of $\mathrm{N}, \mathrm{N}, \mathrm{N}, \mathrm{N}-$ tetramethyl-p-phenylenediamine (TMPD) with arachidonic acid according to the protocol of Petrovic and Murray [69], with slight modifications. The activity of the EO or ibuprofen as a reference drug at a concentration range of $0.98-125 \mu \mathrm{g} \mathrm{mL}^{-1}$ was determined by monitoring the absorbance of TMPD oxidation reaction with arachidonic acid at $611 \mathrm{~nm}$ using a microplate reader (BioTek Instruments Inc., Winooski, VT, USA). The inhibition percentage and $\mathrm{IC}_{50}$ were calculated as previously mentioned in the membrane stabilization inhibition assay.

\subsection{Treatment of Data}

The experiment of allelopathic bioassay was repeated three times with five replicas per each treatment. The data were subjected to one-way ANOVA followed by Tukey's HSD at the probability level of 0.05 using CoStat software program, version 6.311 (http: / / www.cohort.com, CoHort, Monterey, CA, USA, 1 April 2017). Additionally, the antioxidant scavenging data were subjected to one-way ANOVA followed by Tukey's HSD. The data of anti-inflammatory activity were compared using paired two-tailed $t$-tests using the XLSTAT 2018 program (https:/ / www.xlstat.com/en/, Addinsoft Inc., New York, NY, USA, 15 January 2018). Chemometric analysis of the EO compositions of the studied Egyptian ecospecies in the present study and four other studied ecospecies collected from Saudi Arabia [28], Tunisia [37], Iran [27], and the United Arab Emirates [26] was performed via cluster analysis (agglomerative hierarchical clustering (AHC) and principal components analysis (PCA). We constructed a matrix of 65 compounds, from six samples of $C$. amblyocarpa, with a concentration $>2 \%$. The matrix was subjected to AHC and PCA using the XLSTAT 2018 program (https: / / www.xlstat.com/en/, Addinsoft Inc., New York, NY, USA, 15 January 2018).

\section{Conclusions}

For the first time, the analysis of the EO from the above-ground parts of the Egyptian ecospecies of C. amblyocarpa revealed the presence of 48 compounds, with a prevalence of sesquiterpenes. Caryophyllene oxide, hexahydrofarnesyl acetone, alloaromadendrene epoxide, myrtenyl acetate, isoshyobunone, shyobunol, and trans-caryophyllene have been identified as major compounds. The chemometric analysis of the presently studied ecospecies and other reported ecospecies revealed significant variation in the EO composition that could be ascribed to variation in the environmental and climatic conditions. EO showed substantial allelopathic inhibitory activity against the weed D. aegyptium, reflecting the potentiality of using this EO as an eco-friendly bioherbicide. Additionally, the EO showed significant antioxidant and anti-inflammatory activities. Further studies are recommended for evaluation (i) of anti-inflammatory effects of the C. ambliocarpa EO on an in vitro cell model (ex. RAW 264.7 cells); and (ii) the antioxidant, anti-inflammatory, and allelochemical activities along with the possible modes of action of the pure samples of the main EO compounds either singularly or in combination.

Author Contributions: Conceptualization, A.M.A.-E., A.I.E. and Y.A.E.-A.; formal analysis, A.M.A.E., A.I.E., A.E.-N.G.E.G. and Y.A.E.-A.; investigation, A.M.A.-E., A.I.E., A.M.E., T.A.M. and Y.A.E.-A.; Validation, A.M.A.-E. and A.I.E.; writing—original draft preparation, A.M.A.-E. and A.I.E.; writing- 
review and editing, A.M.A.-E., A.M.E., Y.A.E.-A., T.A.M., A.E.-N.G.E.G. and A.I.E. All authors have read and agreed to the published version of the manuscript.

Funding: This research received no external funding.

Institutional Review Board Statement: Not applicable.

Informed Consent Statement: Not applicable.

Data Availability Statement: Not applicable.

Conflicts of Interest: The authors declare no conflict of interest.

Sample Availability: Samples of the compounds are not available from the authors.

\section{References}

1. Poliakoff, M.; Licence, P. Green chemistry. Nature 2007, 450, 810-812. [CrossRef] [PubMed]

2. Poliakoff, M.; Fitzpatrick, J.M.; Farren, T.R.; Anastas, P.T. Green chemistry: Science and politics of change. Science 2002, 297, 807-810. [CrossRef]

3. Horváth, I.T.; Anastas, P.T. Innovations and green chemistry. Chem. Rev. 2007, 107, 2169-2173. [CrossRef]

4. Elgamal, A.M.; Ahmed, R.F.; Abd-ElGawad, A.M.; El Gendy, A.E.-N.G.; Elshamy, A.I.; Nassar, M.I. Chemical profiles, anticancer, and anti-aging activities of essential oils of Pluchea dioscoridis (L.) DC. and Erigeron bonariensis L. Plants 2021, 10, 667. [CrossRef]

5. Al-Rowaily, S.L.; Abd-ElGawad, A.M.; Assaeed, A.M.; Elgamal, A.M.; Gendy, A.E.-N.G.E.; Mohamed, T.A.; Dar, B.A.; Mohamed, T.K.; Elshamy, A.I. Essential oil of Calotropis procera: Comparative chemical profiles, antimicrobial activity, and allelopathic potential on weeds. Molecules 2020, 25, 5203. [CrossRef] [PubMed]

6. Assaeed, A.; Elshamy, A.; El Gendy, A.E.-N.; Dar, B.; Al-Rowaily, S.; Abd-ElGawad, A. Sesquiterpenes-rich essential oil from above ground parts of Pulicaria somalensis exhibited antioxidant activity and allelopathic effect on weeds. Agronomy 2020, 10, 399. [CrossRef]

7. Elshamy, A.; Essa, A.F.; El-Hawary, S.S.; El Gawad, A.M.A.; Kubacy, T.M.; El-Khrisy, E.E.-D.A.; Younis, I.Y. Prevalence of diterpenes in essential oil of Euphorbia mauritanica L.: Detailed chemical profile, antioxidant, cytotoxic and phytotoxic activities. Chem. Biodivers. 2021, 18, e2100238.

8. Elshamy, A.I.; Ammar, N.M.; Hassan, H.A.; Al-Rowaily, S.L.; Ragab, T.I.; El Gendy, A.E.-N.G.; Abd-ElGawad, A.M. Essential oil and its nanoemulsion of Araucaria heterophylla resin: Chemical characterization, anti-inflammatory, and antipyretic activities. Ind. Crop. Prod. 2020, 148, 112272. [CrossRef]

9. Edziri, H.; Mastouri, M.; Aouni, M.; Anthonissen, R.; Verschaeve, L. Investigation on the genotoxicity of extracts from Cleome amblyocarpa Barr. and Murb, an important Tunisian medicinal plant. South Afr. J. Bot. 2013, 84, 102-103. [CrossRef]

10. Abd El-Gawad, A.M.; El Gendy, A.E.-N.; El-Amier, Y.; Gaara, A.; Omer, E.; Al-Rowaily, S.; Assaeed, A.; Al-Rashed, S.; Elshamy, A. Essential oil of Bassia muricata: Chemical characterization, antioxidant activity, and allelopathic effect on the weed Chenopodium murale. Saudi J. Biol. Sci. 2020, 27, 1900-1906. [CrossRef]

11. Abd El-Gawad, A.M.; Elshamy, A.I.; El-Amier, Y.A.; El Gendy, A.E.-N.G.; Al-Barati, S.A.; Dar, B.A.; Al-Rowaily, S.L.; Assaeed, A.M. Chemical composition variations, allelopathic, and antioxidant activities of Symphyotrichum squamatum (Spreng.) Nesom essential oils growing in heterogeneous habitats. Arab. J. Chem. 2020, 13, 4237-4245. [CrossRef]

12. Abd El-Gawad, A.M.; El-Amier, Y.A.; Bonanomi, G. Allelopathic activity and chemical composition of Rhynchosia minima (L.) DC. essential oil from Egypt. Chem. Biodivers. 2018, 15, e1700438. [CrossRef]

13. IPNI. The International Plant Names Index; The Royal Botanic Gardens, Kew, Harvard University Herbaria \& Libraries and Australian National Botanic Gardens: Richmond, UK, 2012.

14. IUCN. A Guide to Medicinal Plants in North Africa; IUCN: Barcelona, Spain, 2005.

15. Bouriche, H.; Arnhold, J. Effect of Cleome arabica leaf extract treated by naringinase on human neutrophil chemotaxis. Nat. Prod. Commun. 2010, 5, 415-418. [CrossRef] [PubMed]

16. Khlifi, A.; Pecio, Ł.; Lobo, J.C.; Melo, D.; Ayache, S.B.; Flamini, G.; Oliveira, M.B.P.; Oleszek, W.; Achour, L. Leaves of Cleome amblyocarpa Barr. and Murb. and Cleome arabica L.: Assessment of nutritional composition and chemical profile (LC-ESI-MS/MS), anti-inflammatory and analgesic effects of their extracts. J. Ethnopharmacol. 2021, 269, 113739. [CrossRef] [PubMed]

17. Zaki, A.A.; Al-Karmalawy, A.A.; El-Amier, Y.A.; Ashour, A. Molecular docking reveals the potential of Cleome amblyocarpa isolated compounds to inhibit COVID-19 virus main protease. New J. Chem. 2020, 44, 16752-16758. [CrossRef]

18. Ahmed, A.A.; Kattab, A.M.; Bodige, S.G.; Mao, Y.; Minter, D.E.; Reinecke, M.G.; Watson, W.H.; Mabry, T.J. 15 $\alpha$-Acetoxycleomblynol A from Cleome amblyocarpa. J. Nat. Prod. 2001, 64, 106-107. [CrossRef] [PubMed]

19. Seglab, F.; Hamia, C.; Khacheba, I.; Djeridane, A.; Yousfi, M. High in vitro antioxidant capacities of Algerian Cleome arabica leaves extracts. Phytothérapie 2021, 19, 16-24. [CrossRef]

20. Takhi, D.; Ouinten, M.; Yousfi, M. Study of antimicrobial activity of secondary metabolites extracted from spontaneous plants from the area of Laghouat, Algeria. Adv. Environ. Biol. 2011, 5, 469-477.

21. Abd El-Gawad, A.M.; El-Amier, Y.A.; Bonanomi, G. Essential oil composition, antioxidant and allelopathic activities of Cleome droserifolia (Forssk.) Delile. Chem. Biodivers. 2018, 15, e1800392. [CrossRef] [PubMed] 
22. Muhaidat, R.; Al-Qudah, M.A.; Samir, O.; Jacob, J.H.; Hussein, E.; Al-Tarawneh, I.N.; Bsoul, E.; Orabi, S.T.A. Phytochemical investigation and in vitro antibacterial activity of essential oils from Cleome droserifolia (Forssk.) Delile and C. trinervia Fresen. (Cleomaceae). South Afr. J. Bot. 2015, 99, 21-28. [CrossRef]

23. Ndungu, M.; Lwande, W.; Hassanali, A.; Moreka, L.; Chhabra, S.C. Cleome monophylla essential oil and its constituents as tick (Rhipicephalus appendiculatus) and maize weevil (Sitophilus zeamais) repellents. Entomol. Exp. Appl. 1995, 76, 217-222. [CrossRef]

24. McNeil, M.J.; Porter, R.B.; Williams, L.A. Chemical composition and biological activity of the essential oil from Jamaican Cleome serrata. Nat. Prod. Commun. 2012, 7, 1231-1232. [CrossRef]

25. Sodeifian, G.; Saadati Ardestani, N.; Sajadian, S.A.; Ghorbandoost, S. Application of supercritical carbon dioxide to extract essential oil from Cleome coluteoides Boiss: Experimental, response surface and grey wolf optimization methodology. J. Supercrit. Fluids 2016, 114, 55-63. [CrossRef]

26. Shahin, S.; Kurup, S.; Cheruth, A.-J.; Salem, M. Chemical composition of Cleome amblyocarpa Barr. \& Murb. essential oils under different irrigation levels in sandy soils with antioxidant activity. J. Essent. Oil Bear. Plants 2018, 21, 1235-1256.

27. Rassouli, E.; Dadras, O.G.; Bina, E.; Asgarpanah, J. The essential oil composition of Cleome brachycarpa Vahl ex DC. J. Essent. Oil Bear. Plants 2014, 17, 158-163. [CrossRef]

28. Al-Humaidia, J.Y.; Al-Qudah, M.A.; Al-Saleem, M.S.; Alotaibi, S.M. Antioxidant activity and chemical composition of essential oils of selected Cleome species growing in Saudi Arabia. Jordan J. Chem. 2019, 14, 29-37.

29. Abd El-Gawad, A.M.; El Gendy, A.E.-N.G.; Assaeed, A.M.; Al-Rowaily, S.L.; Alharthi, A.S.; Mohamed, T.A.; Nassar, M.I.; Dewir, Y.H.; Elshamy, A.I. Phytotoxic effects of plant essential oils: A systematic review and structure-activity relationship based on chemometric analyses. Plants 2021, 10, 36. [CrossRef] [PubMed]

30. Elshamy, A.; Abd El-Gawad, A.M.; El-Amier, Y.A.; El Gendy, A.; Al-Rowaily, S. Interspecific variation, antioxidant and allelopathic activity of the essential oil from three Launaea species growing naturally in heterogeneous habitats in Egypt. Flavour Fragr. J. 2019, 34, 316-328. [CrossRef]

31. Hassan, E.M.; El Gendy, A.E.-N.G.; Abd El-Gawad, A.M.; Elshamy, A.I.; Farag, M.A.; Alamery, S.F.; Omer, E.A. Comparative chemical profiles of the essential oils from different varieties of Psidium guajava L. Molecules 2021, 26, 119. [CrossRef]

32. Fernández-Sestelo, M.; Carrillo, J.M. Environmental effects on yield and composition of essential oil in wild populations of spike lavender (Lavandula latifolia Medik.). Agriculture 2020, 10, 626. [CrossRef]

33. Abd-El-Gawad, A.M.; Elshamy, A.; Al-Rowaily, S.; El-Amier, Y.A. Habitat affects the chemical profile, allelopathy, and antioxidant properties of essential oils and phenolic enriched extracts of the invasive plant Heliotropium Curassavicum. Plants 2019, 8, 482. [CrossRef]

34. Abd El-Gawad, A.M. Chemical constituents, antioxidant and potential allelopathic effect of the essential oil from the aerial parts of Cullen plicata. Ind. Crops Prod. 2016, 80, 36-41. [CrossRef]

35. El-Nashar, H.A.S.; Mostafa, N.M.; El-Badry, M.A.; Eldahshan, O.A.; Singab, A.N.B. Chemical composition, antimicrobial and cytotoxic activities of essential oils from Schinus polygamus (Cav.) cabrera leaf and bark grown in Egypt. Nat. Prod. Res. 2020, 34, 1-4. [CrossRef]

36. Sam, L.N.; Huong, L.T.; Minh, P.N.; Vinh, B.T.; Dai, D.N.; Setzer, W.N.; Ogunwande, I.A. Chemical composition and antimicrobial activity of the rhizome essential oil of Curcuma sahuynhensis from Vietnam. J. Essent. Oil Bear. Plants 2020, 23, 803-809. [CrossRef]

37. Khlifi, A.; Chrifa, A.B.; Lamine, J.B.; Thouri, A.; Adouni, K.; Flamini, G.; Oleszek, W.; Achour, L. Gas chromatography-mass spectrometry (GM-MS) analysis and biological activities of the aerial part of Cleome amblyocarpa Barr. and Murb. Environ. Sci. Pollut. Res. 2020, 27, 22670-22679. [CrossRef]

38. McNeil, M.J.; Porter, R.B.; Williams, L.A.; Rainford, L. Chemical composition and antimicrobial activity of the essential oils from Cleome spinosa. Nat. Prod. Commun. 2010, 5, 1301-1306. [CrossRef]

39. Balogun, O.S.; Ajayi, O.S.; Adeleke, A.J. Hexahydrofarnesyl acetone-rich extractives from Hildegardia barteri. J. Herbs Spices Med. Plants 2017, 23, 393-400. [CrossRef]

40. Abd El-Gawad, A.; El Gendy, A.; Elshamy, A.; Omer, E. Chemical composition of the essential oil of Trianthema portulacastrum L. Aerial parts and potential antimicrobial and phytotoxic activities of its extract. J. Essent. Oil Bear. Plants 2016, 19, 1684-1692 [CrossRef]

41. Fayed, E.M.; Abd EI-Gawad, A.M.; Elshamy, A.I.; El-Halawany, E.S.F.; EI-Amier, Y.A. Essential oil of Deverra tortuosa aerial parts: Detailed chemical profile, allelopathic, antimicrobial, and antioxidant activities. Chem. Biodivers. 2021, 18, e2000914. [CrossRef]

42. Saleh, I.; Abd El-Gawad, A.; El Gendy, A.E.-N.; Abd El Aty, A.; Mohamed, T.; Kassem, H.; Aldosri, F.; Elshamy, A.; Hegazy, M.-E.F Phytotoxic and antimicrobial activities of Teucrium polium and Thymus decussatus essential oils extracted using hydrodistillation and microwave-assisted techniques. Plants 2020, 9, 716. [CrossRef]

43. Ladhari, A.; Gaaliche, B.; Zarrelli, A.; Ghannem, M.; Ben Mimoun, M. Allelopathic potential and phenolic allelochemicals discrepancies in Ficus carica L. cultivars. South Afr. J. Bot. 2020, 130, 30-44. [CrossRef]

44. Chon, S.U.; Kim, Y.M.; Lee, J.C. Herbicidal potential and quantification of causative allelochemicals from several Compositae weeds. Weed Res. 2003, 43, 444-450. [CrossRef]

45. Ladhari, A.; Omezzine, F.; DellaGreca, M.; Zarrelli, A.; Zuppolini, S.; Haouala, R. Phytotoxic activity of Cleome arabica L. and its principal discovered active compounds. South Afr. J. Bot. 2013, 88, 341-351. [CrossRef]

46. Ladhari, A.; Tufano, I.; DellaGreca, M. Influence of new effective allelochemicals on the distribution of Cleome arabica L. community in nature. Nat. Prod. Res. 2020, 34, 773-781. [CrossRef] [PubMed] 
47. Razavi, S.M.; Narouei, M.; Majrohi, A.A.; Chamanabad, H.R.M. Chemical constituents and phytotoxic activity of the essential oil of Acroptilon repens (L.) Dc from Iran. J. Essent. Oil Bear. Plants 2012, 15, 943-948. [CrossRef]

48. de Almeida, L.F.R.; Frei, F.; Mancini, E.; De Martino, L.; De Feo, V. Phytotoxic activities of Mediterranean essential oils. Molecules 2010, 15, 4309-4323. [CrossRef]

49. Mancini, E.; Arnold, N.A.; De Martino, L.; De Feo, V.; Formisano, C.; Rigano, D.; Senatore, F. Chemical composition and phytotoxic effects of essential oils of Salvia hierosolymitana Boiss. and Salvia multicaulis Vahl. var. simplicifolia Boiss. growing wild in Lebanon. Molecules 2009, 14, 4725-4736. [PubMed]

50. Abd El-Gawad, A.M.; Elshamy, A.; El Gendy, A.E.-N.; Al-Rowaily, S.L.; Assaeed, A.M. Preponderance of oxygenated sesquiterpenes and diterpenes in the volatile oil constituents of Lactuca serriola L. revealed antioxidant and allelopathic activity. Chem. Biodivers. 2019, 16, e1900278. [CrossRef]

51. Mancini, E.; De Martino, L.; Malova, H.; De Feo, V. Chemical composition and biological activities of the essential oil from Calamintha nepeta plants from the wild in southern Italy. Nat. Prod. Commun. 2013, 8, 129-142. [CrossRef]

52. Peng, S.L.; Wen, J.; Guo, Q.F. Mechanism and active variety of allelochemicals. Acta Bot. Sin. 2004, 46, 757-766.

53. El-Kashak, W.A.; Elshamy, A.I.; Mohamed, T.A.; El Gendy, A.E.-N.G.; Saleh, I.A.; Umeyama, A. Rumpictuside A: Unusual 9,10-anthraquinone glucoside from Rumex pictus Forssk. Carbohydr. Res. 2017, 448, 74-78. [CrossRef]

54. de Santana Souza, M.T.; Almeida, J.R.G.d.S.; de Souza Araujo, A.A.; Duarte, M.C.; Gelain, D.P.; Moreira, J.C.F.; dos Santos, M.R.V.; Quintans-Júnior, L.J. Structure-activity relationship of terpenes with anti-inflammatory profile-A systematic review. Basic Clin. Pharmacol. Toxicol. 2014, 115, 244-256. [CrossRef] [PubMed]

55. Rodrigues, L.B.; Martins, A.O.B.P.B.; Ribeiro-Filho, J.; Cesário, F.R.A.S.; e Castro, F.F.; de Albuquerque, T.R.; Fernandes, M.N.M.; da Silva, B.A.F.; Júnior, L.J.Q.; de Sousa Araújo, A.A. Anti-inflammatory activity of the essential oil obtained from Ocimum basilicum complexed with $\beta$-cyclodextrin ( $\beta$-CD) in mice. Food Chem. Toxicol. 2017, 109, 836-846. [CrossRef]

56. Kumar, R.; Kumar, R.; Prakash, O.; Srivastava, R.; Pant, A. Chemical composition, in vitro antioxidant, anti-inflammatory and antifeedant properties in the essential oil of Asian marsh weed Limnophila indica L. (Druce). J. Pharmacogn. Phytochem. 2019, 8 , 1689-1694.

57. De Cássia Da Silveira e Sá, R.; Andrade, L.N.; De Sousa, D.P. Sesquiterpenes from essential oils and anti-inflammatory activity. Nat. Prod. Commun. 2015, 10, 1767-1774. [CrossRef]

58. Chavan, M.; Wakte, P.; Shinde, D. Analgesic and anti-inflammatory activity of caryophyllene oxide from Annona squamosa L. bark. Phytomedicine 2010, 17, 149-151. [CrossRef]

59. Passos, G.F.; Fernandes, E.S.; da Cunha, F.M.; Ferreira, J.; Pianowski, L.F.; Campos, M.M.; Calixto, J.B. Anti-inflammatory and anti-allergic properties of the essential oil and active compounds from Cordia verbenacea. J. Ethnopharmacol. 2007, 110, 323-333. [CrossRef]

60. Medeiros, R.; Passos, G.; Vitor, C.; Koepp, J.; Mazzuco, T.; Pianowski, L.; Campos, M.; Calixto, J. Effect of two active compounds obtained from the essential oil of Cordia verbenacea on the acute inflammatory responses elicited by LPS in the rat paw. Br. J. Pharmacol. 2007, 151, 618-627. [CrossRef]

61. Foddai, M.; Marchetti, M.; Ruggero, A.; Juliano, C.; Usai, M. Evaluation of chemical composition and anti-inflammatory, antioxidant, antibacterial activity of essential oil of Sardinian Santolina corsica Jord. \& Fourr. Saudi J. Biol. Sci. 2019, $26,930-937$.

62. Touaibia, M. Composition and anti-inflammatory effect of the common myrtle (Myrtus communis L.) essential oil growing wild in Algeria. Phytotherapie 2020, 18, 156-161. [CrossRef]

63. Tackholm, V. Students' Flora of Egypt, 2nd ed.; Cairo University Press: Cairo, Egypt, 1974.

64. Boulos, L. Flora of Egypt; All Hadara Publishing: Cairo, Egypt, 1995; Volume 1.

65. Abd El-Gawad, A.; Elshamy, A.; El Gendy, A.E.-N.; Gaara, A.; Assaeed, A. Volatiles profiling, allelopathic activity, and antioxidant potentiality of Xanthium strumarium leaves essential oil from Egypt: Evidence from chemometrics analysis. Molecules 2019, $24,584$. [CrossRef]

66. Miguel, M.G. Antioxidant activity of medicinal and aromatic plants. Flavour Fragr. J. 2010, 25, 219-312. [CrossRef]

67. Shinde, U.; Phadke, A.; Nair, A.; Mungantiwar, A.; Dikshit, V.; Saraf, M. Membrane stabilizing activity-A possible mechanism of action for the anti-inflammatory activity of Cedrus deodara wood oil. Fitoterapia 1999, 70, 251-257. [CrossRef]

68. Granica, S.; Czerwińska, M.E.; Piwowarski, J.P.; Ziaja, M.; Kiss, A.K. Chemical composition, antioxidative and anti-inflammatory activity of extracts prepared from aerial parts of Oenothera biennis L. and Oenothera paradoxa Hudziok obtained after seeds cultivation. J. Agric. Food Chem. 2013, 61, 801-810. [CrossRef] [PubMed]

69. Petrovic, N.; Murray, M. Using N,N,N $\mathrm{N}^{\prime} \mathrm{N}^{\prime}$-tetramethyl-p-phenylenediamine (TMPD) to assay cyclooxygenase activity In Vitro. In Advanced Protocols in Oxidative Stress II; Armstrong, D., Ed.; Humana Press: Totowa, NJ, USA, 2010; pp. 129-140. [CrossRef] 